\title{
PERMASALAHAN TENTANG HAK PATEN
}

\author{
M REZA FAHLEPI \\ Fakultas Komputer \\ muhammadrezapahlevi.student@umitra.ac.id
}

\begin{abstract}
Paten adalah hak eksklusif yang diberikan oleh Negara kepada penemu atas hasil penemuannya di bidang teknologi, yang untuk selama waktu tertentu melaksanakan sendiri Invensinya tersebut atau memberikan persetujuannya kepada pihak lain untuk melaksanakannya. (UU 14 tahun 2001, ps. 1, ay. 1).

Sementara itu, arti Invensi dan Inventor (yang terdapat dalam pengertian di atas, juga menurut undang-undang tersebut, adalah):

- Invensi adalah ide Inventor yang dituangkan ke dalam suatu kegiatan pemecahan masalah yang spesifik di bidang teknologi dapat berupa produk atau proses, atau penyempurnaan dan pengembangan produk atau proses. (UU 14 tahun 2001, ps. 1, ay. 2)

- Inventor adalah seorang yang secara sendiri atau beberapa orang yang secara bersama-sama melaksanakan ide yang dituangkan ke dalam kegiatan yang menghasilkan Invensi. (UU 14 tahun 2001, ps. 1, ay. 3)

Kata paten, berasal dari bahasa inggris patent, yang awalnya berasal dari kata patere yang berarti membuka diri (untuk pemeriksaan publik), dan juga berasal dari istilah letters patent, yaitu surat keputusan yang dikeluarkan kerajaan yang memberikan hak eksklusif kepada individu dan pelaku bisnis tertentu. Dari definisi kata paten itu sendiri, konsep paten mendorong inventor untuk membuka pengetahuan demi kemajuan masyarakat dan sebagai gantinya, inventor mendapat hak eksklusif selama periode tertentu. Mengingat pemberian paten tidak mengatur siapa yang harus melakukan invensi yang dipatenkan, sistem paten tidak dianggap sebagai hak monopoli.
\end{abstract}


Fakultas Komputer

M REZA FAHLEPI

Penjelasan Mengenai Paten Dan Sistem Yang Diterapkan Di Indonesia Mengenai Proses Permohonan Hak Paten 


\section{A. INTRODUCTION}

\section{DEFINISI}

Pengertian hak paten telah diatur dalam Undang Undang No 14 Tahun 2001 tentang paten. Dalam undang-undang ini diatur mengenai syarat paten, jangka waktu berlakunya paten, hak dan kewajiban inventor sebagai penemu invensi, tata cara permohonan hak paten, pegumuman dan pemeriksaan substansif dll. Dengan adanya undangundang ini maka diharapkan akan ada perlindungn terhadap kerya intelektual dari putra dan putri Indonesia. Yang menjadi obyek hak paten ialah temuan (invention) yang secara praktis dapat dipergunakan dalam bidang perindustrian. Itulah sebabnya Hak Paten termasuk dalam jenis hak milik perindustrian, yang membedakannya dengan Hak Cipta. Penemuan yang dapat diberikan hak paten hanyalah penemuan baru di bidang teknologi. Penemuan dimaksud, bisa berupa teknologi yang ada dalam produk tertentu maupun cara yang dipakai dalam proses menghasilkan produk tertentu. Sehingga hak paten bisa diberikan pada produk maupun teknologi proses produksi.

\section{Masalah Hak Paten 1 (Microsoft vs Google)}

Microsoft vs Google berawal dari tuntutan Google kepada Microsoft untuk ganti rugi sejumlah uang karena telah melanggar hak paten Google. Microsoft dituding menggunakan teknologi yang telah dipatenkan Motorola di Xbox dan tablet Surface miliknya. Salah satu pakar Motorola memberikan testimoni ke pengadilan Seatle, Amerika Serikat bahwa Microsoft akan mendapatkan profit sebesar US\$94 miliar dari penjualan produk-produknya tersebut hingga tahun 2017. Pihak Motorola menuntut royalti paten tahunan sebesar US $\$ 4$ miliar untuk teknologi wireless dan video yang dipakai Microsoft di Xbox dan tablet Surfece. Namun Microsoft merasa mereka hanya perlu membayar biaya lisensi saja sebesar US $\$ 1$ juta saja per tahun. Apabila ini disetujui hakim maka Motorola akan kehilangan posisi tawar dalam masalah lisensi Google dengan rival-rivalnya. 
Perusahaan mobile Motorola yang dibeli Google pada bulan Mei lalu ketika terancam bangkrut dirasa masih memiliki kekuatan di sisi produk dan hak paten. Karena itu Google rela membeli perusahaan ini seharga US\$12.5M. Tentunya Google tidak mau melepas begitu saja hak-hak yang dimiliki Motorola ketangan-tangan pesaingnya. Sidang Google vs Microsoft ini akan berlangsung dalam satu minggu untuk memeriksa berapa royalti yang harus dibayar Microsoft ke pada pihak Google.

\section{Penyelesaian}

Hakim administrasi U.S International Trade Commision, telah memberikan putusannya pada Jum'at, tanggal 25/03/2013 terkait masalah XBOX besutan Microsoft vs Motorola. Putusannya adalah, bahwa Hakim tidak menemukan pelanggaran terkait masalah paten yang dilaporkan oleh Motorola. Lebih lengkapnya, Hakin David P. Shaw mengatakan bahwa XBOX tidak melangar hak paten terhadap seksi 337 of the Traffic Act tahun 1930.

\section{B. CONCLUSION}

Hakim administrasi U.S International Trade Commision, telah memberikan putusannya pada Jum'at, tanggal 25/03/2013 terkait masalah XBOX besutan Microsoft vs Motorola. Putusannya adalah, bahwa Hakim tidak menemukan pelanggaran terkait masalah paten yang dilaporkan oleh Motorola. Lebih lengkapnya, Hakin David P. Shaw mengatakan bahwa XBOX tidak melangar hak paten terhadap seksi 337 of the Traffic Act tahun 1930.

\section{ACKNOWLEDGEMENT}

University Of Indonesia University Of Mitra Indonesia

Telkom University

University Of Mellbourne

Saitama University 


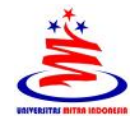


D. REFERENCE (Based ISO 690)

A. S. Putra And O. M. Febriani, "Knowledge Management Online Application In Pdam Lampung Province," In Prosiding International Conference On Information Technology And Business (Icitb), 2018, Pp. 181-187.

[2] A. S. Putra, O. M. Febriani, And B. Bachry, "Implementasi Genetic Fuzzy System Untuk Mengidentifikasi Hasil Curian Kendaraan Bermotor Di Polda Lampung," J. Sist. Inf. Dan Manaj. Basis Data, Vol. 1, No. 1, Pp. 21-30, 2018.
Riset Standardisasi Industri Bandar Lampung," J. Inform., Vol. 13, No. 1, Pp. 90-98, 2014. [4] Putra, Arie Setya. "2018 Artikel Struktur Data, Audit Dan Jaringan Komputer." (2018).

[5] Putra, A. S. (2018, July 17). Paperplain Fundamental Create Application With Borland Delphi 7.0 University Of Mitra Indonesia. Retrieved From Osf.Io/Pbrn9.

\section{E. REFERENCE (Based APA)}

Putra, A. S., Aryanti, D. R., \& Hartati, I. (2018, November). Metode SAW (Simple Additive Weighting) sebagai Sistem Pendukung Keputusan Guru Berprestasi (Studi Kasus: SMK Global 
Surya). In Prosiding Seminar Nasional

Darmajaya (Vol. 1, No. 1, pp. 85-97).

Sari, D. P., Febriani, O. M., \& Putra, A. S. (2018, November). Perancangan Sistem Informasi SDM Berprestasi pada SD Global Surya. In Prosiding Seminar Nasional Darmajaya (Vol. 1, No. 1, pp. 289-294).

Putra, A. S. (2018). Paperplain: Execution Fundamental Create Application With Borland Delphi 7.0 University Of Mitra Indonesia.

Putra, A. S., Sukri, H., \& Zuhri, K. Sistem Monitoring Realtime Jaringan Irigasi Desa (JIDES) Dengan Konsep Jaringan Sensor Nirkabel. IJEIS (Indonesian Journal of Electronics and Instrumentation Systems), 8(2), 221232.

Darmawan, A., Yuliawati, D., Marcella, O., \& Firmandala, R. (2016). Sistem Absensi dan Pelaporan Berbasis Fingerprint dan SMS Gateway. EXPLORE, 7(1).
Febriani, O. M., Wahyuni, T., \& Yusuf, S. (2017). DESIGN OF WEBSITEBASED INFORMATION SYSTEM FOR EDOCUMENT ADMINISTRASI IN THE COMMUNITY SERVICE UNIT (A Case Study at Rajabasa District). INTERNATIONAL JOURNAL OF COMPUTERS \& TECHNOLOGY, 16(7), 7010-7020.

Febriani, O. M., \& Wahyuni, T. (2017, October). PERANCANGAN SISTEM E-DOCUMENT ADMINISTRASI LOGBOOK PENELITIAN PADA UNIT LAYANAN DI BANDAR LAMPUNG. In Prosiding Seminar Nasional Darmajaya (Vol. 1, No. 1, pp. 187-194).

Febriani, O. M., \& Permadi, A. B. (2017). Implementasi Sistem Aplikasi Data Bimbingan dan Pelanggaran Siswa pada Sekolah Menengah Atas di Lampung Tengah dengan Metode Analisis dan Desain Sistem Terdistribusi (SSAD). EXPERT, 7(1). 
Febriani, O. M., \& Ambarwati, L. (2015). PERANCANGAN APLIKASI PENGOLAHAN DATA PENJUALAN UKM KELANTING KHAS TELO DESA SIDOHARJO KECAMATAN JATI AGUNG KABUPATEN LAMPUNG SELATAN. Jurnal Teknologi Informasi dan Bisnis Pengabdian Masyarakat Darmajaya, 1(1), 77-95.

Febriani, O. M. (2015). Rancang Bangun Aplikasi Ecommercemenggunakan Freewebstore pada UKM Kelanting di Desa Sidoharjo Lampung Selatan. Prosiding Sembistek 2014, 1(02), 446-458. 